\title{
Aeng Visual Ornament of The Surakarta Palace's Building
}

\author{
Rahmanu Widayat ${ }^{1}$, Anung B Studyanto ${ }^{2}$ \\ ${ }^{1}$ Interior Designs Study Program, Fine Arts and Designs Faculty UNS, Solo, Indonesia \\ ${ }^{2}$ Interior Designs Study Program, Fine Arts and Designs Faculty UNS, Solo, Indonesia \\ rahmanuwidayat@staff.uns.ac.id (Rahmanu Widayat), masanung_bs@yahoo.co.id (Anung B Studyanto)
}

\begin{abstract}
Problems arise when building ornaments are considered to be not useful by architects and the modern world of architecture. Ornaments had been presented as important parts of the royal palace buildings from the time of Ancient Egypt until the Renaissance era. It is not so different from what happens in Indonesia; ornaments adorn temples, royal palaces, until the arrival of modern influences which make ornaments no longer appreciated and even hated. The modern concept (of the architecture world), in its development, has become less able to solve various problems, so that the presence of the local ethnic culture (like ornament) has been longed to come back. The ornament ends up paradoxically, standing between hate and longing. By using wangun point of view, an aesthetic concept taken from Javanese culture, an interesting finding shows that the ornament has its own dynamics, not merely as a heritage passed down from generation to generation. Ki Praja Sukemi, an architect of The Kasunanan Surakarta Palace, pioneered the creation of new style ornaments, combination between Javanese and Western (European) styles, and created the Aèng (peculiar) ornament, which is categorized as Kajiman (inspired from the world of Jinn) ornament. This paper will discuss the form, meaning, and aesthetics of these ornaments according to the cultural background of Surakarta Palace.
\end{abstract}

Keywords: Aèng, Ornamen, Surakarta Palace

\section{Introduction}

This study is important considering that building ornaments at a certain period have a very significant role. Ornaments make a building beautiful and full of meaning. At certain moments, ornament has also been considered as bad and rejected for its presence as a decorative for building. The general studies show that ornaments are in fact necessary because it can enhance the beauty of a building exterior look and the interior design. Ornaments beautify the outer appearance of a building including walls, roofs, and kemancak, roof top decorations of a building. Ornaments also beautify the interior of building such as on its walls, columns, doors, windows, ventilation, and ceiling. Ornaments in buildings, in addition to being beautiful, are also rich in symbolic meaning associated with the suggestion, prohibition, and expectations.

Looking back at the development of architecture and interior in the world, ornaments have been decorating the royal palace buildings since the days of the Ancient Egypt, Persia, Greece, Rome, the Middle Ages (Gothic and Romanesque), and the Renaissance. After the renaissance era, the Baroque and Rococo ornament style appeared and adorned many royal palaces. It was then followed by the Neo-Classic ornaments, Art Nouveu and Art Deco. In the Indonesian territory today, ornaments can be traced from the relics of temple buildings of the periods of Central Java and East Java. Ornaments adorned the palaces of kingdoms in Java such as the 14th-century Majapahit, in which all houses had strong and beautifully carved pillars which were colourfully made (Muljana, 2007: 5). Demak Kingdom Ornament can be seen today in Demak Mosque. Ornaments inherited from the Mataram Islam era can also be found today in the palace building of Surakarta Palace and Yogyakarta Palace.

Some previous studies show that ornaments are beautiful. The book by Van der Hoop, entitled Indonesche Siermotiven (1949), contains beautiful ornament documentations in Indonesia illustrated with drawing techniques, and it was written when Indonesia was still under the Dutch colonization. The book entitled Arsitektur Tradisional Daerah Istimewa Yogyakarta (Traditional Architecture Book of Special Region of Yogyakarta) (1986), edited by Sugiarto Dakung, which is completed with the study of ornament, shows that ornament serves to add to the beauty of building. Joglo Arsitektur Rumah Tradisional Jawa book (Joglo Javanese Traditional House Architecture) (1986), written by R. Ismunandar K., also shows that ornaments improves the beauty of buildings. Soegeng Toekio M also wrote a book entitled Mengenal Ragam Hias Indonesia (Understanding the Variety of Indonesian Ornaments) (1987) which shows beautiful ornaments in Indonesia. In 1998 Pepin van Roojen published Indonesian Ornamental Design, containing beautiful ornaments, but with little explanation. The book 
Ornamen Nusantara Kajian Khusus tentang Ornamen Indonesia (Ornament Nusantara, Special Study on Indonesian Ornament) (2009), written by Aryo Sunaryo, is also similar to the previous writings that show ornament is basically beautiful.

Overall, there are no books that mention criticism on ornaments, while in fact there are many anti-ornament groups who consider that ornament is bad. As the modern times hit the world, the ornaments receded and did not appear again in modern architecture and interiors. Not much different from Indonesia, after the independence in 1945, as the emergence of modern buildings, ornaments also lost its place. Ornaments are considered insignificant as opposed to the principles of modern buildings without ornamentation. In fact, there are some opinions from the Indonesian people themselves in the '80s who glorify designs (when it was a new subject in Indonesia), who despise the ancestral heritage ornaments and mocked with the term "kriwil".

Kriwil ... kriwil ... kriwil ..........

Kriwil ... kriwil ... kriwil ..........

Kriwil means an extraordinarily unique thing, because the whole parts is covered by ornaments and complicated carvings. Perhaps kriwil are components that hang because of loose bolts or excess decoration. So it seems more like a spacecraft that has been infected with earthworm. The philosophy of kriwil is our at titude that still glorifies the traditional-feudalist things, full of intricate ornamental thoughts. Kriwil can infect wooden furniture, silver handicrafts, or even airplanes. Perhaps also kriwil is manifestation of hands that cannot compile mathematical sentences like robots or machines (Sachari, 1986: 22).

Not only the term kriwil that has negative conotation, even in Europe, an architect from Austria once said that "putting ornaments in a building is a crime" (Tanudjaja, 1992: 4).

Fundamentally, the categorization of ornaments as beautiful or not beautiful (bad or crimes) depends on who is arguing. The opinions embracing that ornament is all beautiful are based on the definition of the ornament itself. Ornaments are beautiful figures that are added or deliberately created for the purpose of decoration (their function is to beautify). Opinions that consider ornament is not beautiful are based on different perspectives such as the modern architect's perspective that tends to be anti ornament. This is influenced by Louis Henri Sullivan's slogan of "form follows function" (Tanudjaja, 1992: 4). Based on this principle, any form that has no function is considered bad including the figures of ornaments.

Regardless the above opinions, there is a more flexible way of assessing ornaments. Javanese ornaments should be understood by the Javanese way, which is to measure the Javanese ornament with the concept of beauty that is perceived from the Javanese way of thinking. In order to assess the beauty of Western cultural product ornaments, the Western way or the aesthetic formulation of Western ornaments is used, as well as modern buildings viewed from the perspective of modern aesthetics. The problem is, if the ornament is a result of a combination between Javanese and Western (European) ornaments, as in the Surakarta Palace building, how should it be assessed? Actually, combining elements of different styles, periods, or geographical areas has been well known in the aesthetic theory in the West as the Eclectic style (Susanto, 2012: 116). Of course in order to examine the eclectic style of Javanese and Western ornaments, there should be a different method. This shows the existence of a gap in the study related to it. The purpose of this paper is to present the figures, to explore meaning, and to express the aesthetics of Javanese and Western Javanese ornaments. This is in line with the authors' current activity, applying the findings of wangun concept (the Javanese aesthetics related to the writer's dissertation topic) in various research and creation opportunities, such as Redesigning of Borobudur Chair with Wangun Concept, Exploration of Borobudur Chair Design Development with Aèng Concept (aèng is the anti thesis of wangun concept) and others. The main finding in this research is a method to study unusual or strange ornaments that are grouped in the world of Jinn (Kajiman) with the concept of wangun, resulting in aeng ornaments. The composition of this article is started with title, abstract, keyword, introduction, literature and theory, data and methods, result and discussion, and ended with conclusion.

\section{Literature and Theory}

There have not been many research results in Java which study the beauty of fine art products with an approach which is derived from the mind of the Javanese people themselves. Many of the studies assess the beauty of the Javanese fine arts with Western theory approach. The concept of beauty which is commonly applied is the Western formalism.

Formalism views art for the sake of art itself and emphasizes that it is the only form used to judge works of art. Aesthetic value is autonomous and not bound by other values such as religion, economy, social, culture, politics and others (Marianto, 2002: 54).

The Westerners are proud to be able to assess all kinds of beauty with their formal aesthetic formula which they consider as universal. Many of fine arts and designs researches on material objects in Indonesia are studied by using the formal Western aesthetic formula.

The Eastern aesthetic theory particularly Javanese (kejawèn) in this article refers to the concept of wangun, ora wangun, or aèng (roughly translated as commonly acceptable, commonly unacceptable, or strange). This concept does not only focus on the Javanese aesthetic formalism but also seek to discover the meaning in various contexts. Wangun fine art ornament refers to the concept of rupa wangun which is guided by the Javanese people mind frame which consists of; 1) figure of manunggaling kawula Gusti (a figure pointing to one spot above), 2) figure of loro-loroning atunggal, an arrangement of two elements left and right, 3) figure of telu-teluning atunggal, an arrangement of three elements left-middle-right/bottom, middle, above, 4) figure of papat keblat kalima pancer, an arrangement of four elements with one centre, 5) figure of nawa rupa, an arrangement of eight elements with one 
centre (Widayat, 2016: 273-274). Basically, the Javanese classic ornaments are based on the concept of rupa wangun above.

The combined ornaments between Javanese and Western styles are classified as ora wangun and aèng.

The term ora wangun is theopposite of the term wangun. It has similarity with the word èlek (ugly) or ala-awon (bad), ora pantes, ora patut (innappropriate), biasa, ora trep, wagu (weird) or ora luwes, kaku (awkward). Ora wangun in English means ugly, inappropriate, common, not suitable, not properly fitting, not flexible / adaptive, and awkward. The shape of figure and the positioning of barang kagunan (art work) is considered ora wangun if it does not follow the nature of the Javanese people mind frame (Widayat, 2016: 216).

The word aèng means élok, nggumunaké, anèh (exquisite, extraordinary, peculiar) (Drafting Team of, KBJ (Javanese Language Great Dictionary), 2001: 5) or beautiful, and weird. Aèng is connoted as anèh (weird) or ora njawani (not in line with the Javanese ways) when an item is not in line with the principles of the Javanese people mind frame (Widayat, 2016: 216). The term aèng can be used to assess ornaments outside the categories of wangun or ora wangun, like the combination of the Javanese and European style which are considered as strange.

\section{Data and Method}

The data are taken from the ornaments of the buildings in Surakarta palace which have the combination of Javanese and Western styles, and which are included in the strange or aèng category. This study is a qualitative research, and the analysis was conducted through interactive analysis model with three components of data reduction, data presentation, and drawing conclusions or verification (Miles \& Hubermen in Sutopo, 2002: 106). The data reduction includes the building ornaments in Surakarta palace. The data presentation is in the form of ornaments with combined styles of Javanese and European or strange ornaments. And then it was followed by drawing conclusions on the strange ornaments. The activities were conducted in an interactive form with the process of collecting data as a cycle process. During the process of conducting research, the researcher worked with the analytical components with the data collected during the ongoing data collection. (Miles \& Hubermen in Sutopo, 2002: 106).

In the research implementation process, the researchers dealt with the analytical components during the ongoing data collections process (Miles \& Hubermen in Sutopo, 2002: 106).

\section{Result and Discussion}

\subsection{Figures of Kajiman Ornament}

Some of the ornaments with combined Javanese and European styles belong to the wangun and ora wangun categories, meaning that they are easy to detect and classify. The figures included as wangun ornament because they reflect the mind frame of the Javanese people mind frame, so they do not seem like a combination of Javanese and Western ornaments. The ornaments are categorized as ora wangun ornaments when the combination between the Javanese and Western styles is out of the mind frame of the Javanese people, resulting in a combination which seems to be forced to unite. There is another type that is not included in the groups of wangun and ora wangun because it is difficult to be identified and included in the classifications. It is then given the name of "Kajiman" ornament, derived from the word "Jinn".

Kajiman ornaments are carved in krawangan (translucent) manner on a field of wood with curved top, then with sungging technique they are coloured with white, light blue, to dark blue and combined into a single unity. This Kajiman ornament is placed above the tèbèng (air vents). The Kajiman ornament was designed by Ki Praja Sukemi, an abdi dalem kalang (a courtier or an architect of Panewu rank). Ki Praja Sukemi was commissioned by the king of The Surakarta Palace, King Paku Buwana X (reigned 1893-1939), to study ornaments and carvings in Bali, in Jepara, and Europe. After studying, under the orders of Paku Buwana X, Ki Praja Sukemi applied his expertise, assisted by carving experts, to decorate the palace building, and resulting in a strange combination of Javanese and European ornaments (Widayat et. al, 2010: 28,29).

Kajiman ornaments are depicted with a left-center-right horizontal arrangement or a figure of telu-teluning atunggal, however, kajiman ornaments are visually less suitable to be called Javanese ornaments. In the middle of the ornament, there is a writing saying PB X (Paku Buwana $\mathrm{X})$ which is presented in curved motif ornaments. If this ornament is identified, it is similar to the appearance of a European cup complete with a king's crown-like cover.

On the right and left side of Kajiman ornament, there is a stylization in the form of swans which are putting their heads into their wings, strange swans ornamentation because their heads are hidden. A visible excessive swans comb stylizations snaking upwards to hold the cup. The swan's neck is made in a circular snake-like figure, and in the centre of the circle, a Ceplok motif (like a grating wheel) is added and on the swans' tail a curved and extending motif of Javanese-style plants is added. Overall, it seems like a spinster depicting a mixture of swans and serpents shapes that distillate like plants which is similar with ornamental figures in Europe during the renaissance era. This form of swan and serpent merging is unusual and it is later named as Kajiman ornament, derived from the word Jim / Jinn. Jim in Javanese language is a spirit that has a mind like humans, while the term Kajiman has a sense of the nature or the world of jinn. Humans can hardly imagine the world of jinn, so that strange and unclassified ornaments are included in the natural category of jinn (Kajiman). In the Western world, Jin is known as Genie which comes from the Middle Eastern fairy tale, commonly portrayed like the Jin which comes out of Aladin's magic lamp when rubbed three times. The ornamental element which can be associated is the magic lamp which is also well known in various countries (see: https://www.aliexpress.com/itemimg/Statue-decoration-factory-outlets-Handmade-lamp- 
Colored-Tea-Pot -Genie-Lamp-Vintage-Retro

\section{6.html).}

Another ornament which belongs to the Kajiman group is in the form of a cup inscribed with the PB X and on its left and right, the motifs of a combination of swans (like birds) and serpents and flora are depicted. It is a stranger description than the previous element. In this ornament, the swans's heads are not hidden anymore but they are revealed, and the swans's heads are turned upward.

\subsection{The Meaning of Kajiman Ornament}

The element of Kajiman ornaments are the cup in the middle, a combination of swans, serpents, and flora in left and right. The cup is a European ornament containing wine, a winning symbol, complemented with the crown stylization and PB X inscription which means Paku Buwana $X$. In the context of Javanese culture, Paku Buwana $X$ is a powerful and very intelligent king. Swans in Western and Hindu cultures are used as symbols, the explanation is as follows.

Swan, combining the two elements of air and water, the swan is the bird of life; the dawn of day; solar. ...

Hindu: Two swan together are that pair of swans who are Ham and Sa, dwelling in the mind of the Great, who subsist entirely on the honey of the blooming lotus of knowledge'. The Hamsa bird is carved on temples and symbolizes the perfect union towards which the celestial beings fly (Cooper, 1998: 164).

Swans is a combination of two elements, namely air and water. Swans are symbol of life, dawn, and light. A pair of swans in Hindu concepts is Ham and Sa (swan), a symbol of intelligence. The swans carved on the temple are the symbol of perfect union flying into the sky. As for the serpent or dragon element, they have two conflicting symbolizations, namely as a symbol of god and also a demon. The eastern society thinks the dragon is a symbol of strength, wisdom, and knowledge, unlike in the monotheistic religion in which the serpent is the representation of devil which deceived Adam and Eve to eat the kuldi fruit which made them know of lust, causing them to be thrown out of heaven into the world (Cooper 1998: 55-56). The serpent or dragon in Javanese culture is a symbol of protection that is reflected in the Naga Anantaboga (Anantaboga Dragon) character (Widayat, 2016: 165). The meaning of Kajiman ornaments can be concluded that The King, in this case Paku Buwana X was a powerful and intelligent king guarded not only by humans but also creatures from the unseen world. This shows that not only humans are subject to the king, but the creatures in the unseen world are also obedient to him, and helped guarding the intelligent and powerful king.

\subsection{Aes thetics of Kajiman Ornament}

When interpreted according to the making process, Kajiman ornament is a creation to realize a new style in Surakarta Palace. This new style is one of the contents of the Giyanti Agreement 1755 between the Surakarta and Yogyakarta Royal Palaces. Surakarta will develop itself with a new style, while Yogyakarta continues the tradition of Mataram. As observed by H. Maclaine Pont - observer of Javanese architecture, buildings in Surakarta are more accepting to the Dutch influence and more accepted by the people of Surakarta. Yogyakarta clings more to the authenticity of traditional cultural arts (Soekiman, 2011: $110)$.

Kajiman ornaments as a new style product of Surakarta Palace is included in ora wangun category in relation to the Islamic Mataram culture, but more visually it is closer to the concept of aèng. The "inner structures" of kajiman ornaments are still based on the arrangement of the wangun figure of telu-teluning atunggal, horizontal arrangement of left-center-right. However, the "outer structure" is aèng. They are Categorized as Aèng because the figures are decorated with ornamental elements that are less prevalent in the Javanese culture; the cup in the middle plus the left and right elements of a mixture of swans, snakes, and flora (Kajiman). This ornament if seen from wangun concept is included in aèng category. Aèng can be wangun when the object is loved or become a trend. Aèng can also be wangun when it becomes a custom (pakulinan or considered as commonly acceptable). Aèng can be wangun if it gets the legitimacy from the king (in royal era). (Widayat, 2016: 216). Kajiman ornament was made under the order of king Paku Buwana X, thus it can be considered as wangun, but wangun outside the standard of the Javanese people mind frame, and when studied in depth there is something that feels odd.

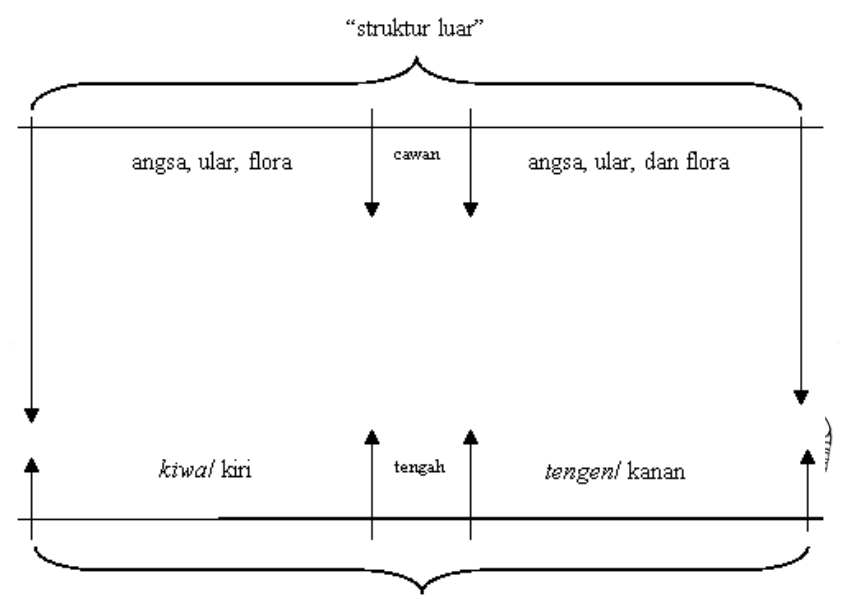

Figure 1. Kajiman Ornament, in the middle, a stylization of a cup with inscription of PB X, the cup cover looks like a crown. On the left and right, stylizations of swans with their heads hidden, combined with stylizations of serpent and flora, resulting in aèng ornament (Ornament source: Widayat et. al. 2010:36)

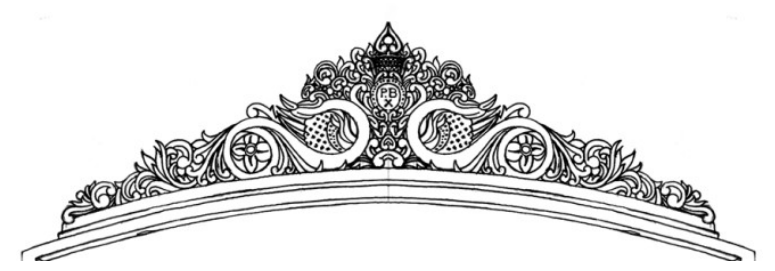

Gambar 2. Kajiman Ornament, with the swans' heads (bird-like) facing upwards, less prevalent for Javanese ornaments and seems aèng (Ornament Source: Widayat et. al. 2010:36) 
Although it seems odd, the Kajiman Ornament in the Aèng Figure Study of Building Ornaments in Surakarta Palace can make a significant contribution in the field of fine arts and design, both in terms of material object and formal object. Ornaments as material objects still need to be studied, especially the ones with eclectic style that have been integrated with the local culture. Many formal objects can be used as approach to examine ornaments, but according to the authors, it would be more appropriate if the formal object applied, such as aesthetics, is the result the local culture findings or local aesthetics.

\section{Conclusion}

Based on the formulation of the problem, the figures, meaning, and aesthetics of the combined styles of Javanese and Western ornaments in the Surakarta Palace can be summarized as follows. The "outer structures" of the ornaments do not refer to Javanese form, but more like a European adaptation. The "inner structure" is based on the telu-teluning atunggal (three in one) principle with the leftmiddle-right horizontal arrangement. The meaning of the ornament can be understood as the embodiment of the supernatural creatures (Kajiman) that keep the palace in general and the king in particular, from the harms of the unseen threats. The aesthetics of the ornaments is the result of a new style creation by Ki Praja Sukemi referring to the Giyanti Agreement and finally resulting in Aèng figures. The benefits of this discussion is that those who pursue Javanese ornaments buildings, cloth motifs, crafts, and others can learn from Ki Praja Sukemi with the concept of aèng, because it has produced a new style of work. The end result is left to the community to judge whether the ornaments are to be categorized as wangun, ora wangun, or aèng. In relation to the acceptance or rejection regarding ornaments, despite any mockery of the modern view, ornaments should continue to exist, because it is difficult to find common ground in different angles. In fact, the modern style has found its own counter, since it is thought to have become irrelevant by the Post modern's view. Thus there will always be actions and reactions in the dynamic development of science, including arts and especially ornaments.

\section{ACKNOWLEDGEMENT(S)}

The authors would like to express gratitude to $\mathrm{KGPH}$ Puger, a Culturalist of The Surakarta Palace as the resource in the research on Surakarta Palace Building Ornaments in 2010 .

\section{REFERENCES}

[1] S. M. Metev and V. P. Veiko, Laser Assisted Microtechnology, 2nd ed., R. M. Osgood, Jr., Ed. Berlin, Germany: Springer-Verlag, 1998.

[2] Dakung, Sugiarto (Penyunting). 1987. Arsitektur Tradisional Daerah Istimewa Yogyakarta. Jakarta: Departemen Pendidikan dan Kebudayaan Proyek Inventarisasi dan Dokumentasi Kebudayaan Daerah.

[3] Cooper, J.C., An Illustrated Encyclopaedia of Traditional Symbols. London: Tames and Hudson Ltd., 1998.

[4] Ismunandar K., R. 1986. Joglo Arsitektur Rumah Tradisional Jawa. Semarang: Dahara Prize.

[5] Marianto, Dwi M., 2002. Seni Kritik Seni. Yogyakarta: Lembaga Penelitian Institut Seni Indonesia (ISI) Yogy akarta.

[6] Muljana, Slamet. 2007. Negara Kretagama dan Tafsir Sejarahnya. Solo: Tiga Serangkai.

[7] Sachari, Agus. 1986. Desain Gaya dan Realitas: Sebuah Penafsiran Tentang Desain Grafis, Produk, Interior, Tekstil, dan Arsitektur di Indonesia. Bandung: Rajawali dengan INDDES, Kelompok Studi Desain, Jurusan Desain ITB.

[8] Soekiman, Djoko. 2011. Kebudayaan Indis Dari Zaman Kompeni sampai Revolusi. Jakarta: Komunitas Bambu.

[9] Sunaryo, Aryo. 2009. Ornamen Nusantara Kajian Khusus Tentang Ornamen Indonesia. Semarang: Penerbit Dahara Prize.

[10] Susanto, Mikke. 2012. Kumpulan Istilah dan Gerakan Seni Rupa. Yogyakarta \& Bali: DictiArt Lab \& Djagad Art House.

[11] Sutopo, H.B., 2002. Metode Penelitian Kualitatif. Surakarta: Sebelas Maret University Press.

[12] Tanudjaja, F. Christian. J Sinar. 1992. Wujud Arsitektur Sebagai Ungkapan Makna Sosial Budaya Manusia. Yogyakarta: Penerbitan Universitas Atma Jaya Yogyakarta.

[13] Tim Penyusun. 1996. Kamus Besar Bahasa Indonesia. Jakarta: Balai Pustaka.

[14] Toekio M., Soegeng. 1987. Mengenal Ragam Hias Indonesia. Bandung: Penerbit Angkasa.

[15] Hoop, Van der. 1949. Indonesche Siermotieven. Koninklijk Bataviaasch Genootschap van Kunsten en Wetenschappen.

[16] Van Roojen, Pepin. 1998. Indonesian Ornamental Design. Amsterdam and Kuala Lumpur: The Pepin Press.

[17] Widayat, Rahmanu, dkk., 2010. Studi Ragam Hias Bangunan Keraton Surakarta dan Aplikasinya dalam Desain Interior Masa Kini, Laporan Penelitian Hibah Kompetitif, Fakultas Sastra dan Seni Rupa (FSSR), Universitas Sebelas Maret Surakarta.

[18] Widayat, Rahmanu. 2016. Estetika Barang Kagunan Interior Dalem Ageng di Rumah Kapangeranan Keraton Surakarta. Disertasi Program Pascasarjana Institut Seni Indonesia (ISI) Surakarta. 